\title{
Energy Analysis of A Retrofitted Regenerative Gas Turbine Organic Cycle in Ihovbor Power Plant
}

\author{
Osarobo Ighodaro*, Prosper Ochornma*, and Henry Egware* \\ * Department of Mechanical Engineering, University of Benin, Benin City, Nigeria \\ (osarobo.ighodaro@uniben.edu, ochornmaprosper@gmail.com, and okechukwu.egware@uniben.edu)
}

Received: 30.06 .2020 Accepted: 28.01.2021

\begin{abstract}
Gas turbines have gained popularity in power generation application because of its ease in operation, fuel flexibility and low emission of greenhouse gases. When in use as a simple gas turbine (SGT), it has the challenge of low thermal efficiency, which needs improvement to enhance its thermal efficiency and other thermal performances. This paper presents the energy analysis of incorporating a retrofitted combined regenerative gas turbine organic Rankine cycle (CRGTORC) to utilize the exhaust heat from the existing Ihovbor Power plant in Nigeria. The working fluid used in the Organic Rankine Cycle (ORC) section was cyclopentane and the analysis was carried out with the aid of ASPEN HYSYS and REFPROP. The performance of the proposed CRGTORC was compared with the existing SGT. The results obtained revealed that the CRGTORC model increases the net power output, thermal efficiency, overall cycle efficiency and work ratio of the system by $23.53 \%, 62.24 \%$, $54.60 \%$, and $10.21 \%$ respectively. Also, the flue gas losses, specific fuel consumption, and heat rate were reduced by $89.21 \%$, $36.26 \%$, and $36.26 \%$ respectively. Furthermore, it was observed that rise in compressor inlet air temperature lead to increase in specific fuel consumption and heat rate and decrease with net power out, thermal efficiency, cycle efficiency, flue gas losses, and work ratio. Thus, from the simulation results, the existing Ihovbor Power plant performance will be improved by integrating the CRGTORC system and its performance is significantly affected by the ambient inlet air temperature.
\end{abstract}

Keywords: Organic Rankine; Aspen HYSYS; combined; Efficiency; Heat recovery; cyclopentane

\section{Introduction}

Gas turbines are devices that convert thermal energy into mechanical energy. It is mainly arranged in a spool or shaft connection, which consists of an air compressor, a combustion chamber, and a turbine. A generator is usually attached to the main shaft, which converts the mechanical energy from the turbine to electrical energy for power generation applications. The gas turbine has gained wide applications in power generation because of its fuel flexibility, low emission of greenhouse gases compared to coal and ease of operation during the demand of power $[1,2]$.

The gas turbines are subjected to low thermal efficiency as a simple gas turbine application. Due to this limitation, they require modification to enhance their thermal efficiency and performance [3]. The available waste heat from the flue gases in the gas turbine power plant can be harnessed by the heat recovery component to provide heat for combined heat and power systems (CHPs). Combined Cycles Gas Turbine (CCGT) can be used to utilize the exhaust gas heat from the gas turbine power plant where the Heat recovery steam generator acts as the boiler for the bottom cycle.
Combined cycles consist of primary cycles called the toppling cycle that has a high maximum temperature and secondary cycle known as the bottoming cycle with intermediate or low maximum temperature. When the gas turbine is used as a topping cycle in combined cycles for power generation, usually the bottoming cycles are the Rankine cycle. Steam has been the main fluid working fluid used in the Rankine cycle section because of its good features like good thermal incorporation with the gas turbine as toppling cycle, maximum reliability and as results from previous industrial experience [4,5]. Mohanty and Venkatesh [6] analyzed various operating conditions performance of a combined cycle power plant. The work reported that the overall thermal efficiency of $60 \%$ was achieved and stated that the efficiency can be increased up to $65 \%$ by increasing the compressor pressure ratio, turbine inlet temperature, reducing ambient air temperature and HRSG design improvement. The results obtained from the research also mentioned that the performance of the CCGT was influenced maximum compressor pressure ratio and turbine inlet temperature.

Lebele- Alawa and Le-ol [7] studied the design of a combined cycle power plant to improve the design of a 25MW Gas Turbine Plant. The total electrical power output 
supplied by the gas turbine was $25 \mathrm{MW}$, it was assumed that there was no burner in the HRSG. While the steam turbine supplies the remaining $12.9 \mathrm{MW}$ giving a total of $37.9 \mathrm{MW}$; a $51 \%$ increment and a thermal efficiency of $30.25 \%$ was achieved. The specific steam consumption was 3.85 $\mathrm{Kg} / \mathrm{KW}$.hr. More also a power of $12.9 \mathrm{MW}$ was recovered from a heat flow of about 42.46MW which was to be expelled as a waste in the exhaust gas. The work has demonstrated the usefulness of exhaust heat utilization in the combined cycle power plant.

It is observed from previous research works that Combined cycles have better efficiency, increases the power output and better economy than a simple gas turbine. When the exhaust gas temperature is low steam Rankine cycle may not be effective in combined cycle power generation application except supplementary firing is employed to improve the steam condition.

An alternative to the steam Rankine cycle for low temperature application is the use of Organic Rankine cycle (ORC), as a bottoming cycle. This view is supported by Yamamoto et al. [8], which stated that when ORCs are used as bottoming cycles, they have proven good thermodynamic performance ability at low temperatures. The ORC is a low-grade heat to power conversion technique, which functioned like a steam Rankine cycle but uses organic substances as working fluid such as silicon Oils, Hydrocarbons, and Fluorocarbons. ORCs combined cycle has some advantages over steam combined cycle like utilization of low/medium heat grade sources, lower cost in operation/maintenance and able to operates at low pressures [9-11].

The used of ORCs bottoming cycles in combined power plants have been studied previously by; Najjar [12]; Khaljani et al. [13]; Grelet et al. [14] and Mohammadi et $a l$. [15] and it was mentioned in their works the importance of studying ORCs integration to utilize gas turbine flue gas heat. Najjar [12] also analyzed a combination of ORC fluids and cycle layout that resulted in global combined overall efficiency slightly below $42.2 \%$. Also, some ORC research applications are carried out by Chacartegui et al. [4] for intermediate temperature thermo solar power plants with a carbon dioxide toppling cycle, and by Caresana et al. [16]; Yari [17] and Invernizzi et al. [18] for microturbine Combined cycles

Narhilal [19] simulated an Organic Rankine Cycle power plant with n-pentane as the working fluid, with a mass flow rate of $15.5 \mathrm{~kg} / \mathrm{s}$. The turbine inlet pressure and temperature were 14.56 bar and $145^{\circ} \mathrm{C}$ respectively and the outlet pressure and temperature of the condenser were $1.37 \mathrm{bar}$ and $45{ }^{0} \mathrm{C}$ respectively. According to them a thermal efficiency of $14.61 \%$ was achieved with a turbine output power of 1.2MW. Meyer et al. [20] of the University of Canterbury New Zealand carried out a design and building of a $1 \mathrm{KW}$ Organic Rankine Cycle power generator. They used a refrigerant mix known as HFC-M1 as the working fluid. Water at a temperature of $15^{\circ} \mathrm{C}$ and flow rate of $0.5 \mathrm{~kg} / \mathrm{s}$ was used as the coolant in the condenser. The heat source was a $30 \mathrm{KW}$ capstone diesel turbine exhaust at a temperature of $226^{\circ} \mathrm{C}$ and a mass flow rate of $0.3 \mathrm{~kg} / \mathrm{s}$ which was channeled to a thermal oil loop as the heat transfer medium. According to them a thermal efficiency of $5.7 \%$ was achieved.

Kumar et al. [21] carried out a Thermodynamic Analysis of a Regenerative Gas Turbine Cogeneration Plant. In the course of their research work they observed the following; first, as pressure ratio $\left(\mathrm{r}_{\mathrm{p}}\right)$ increases compressor work increases so also turbine work and net work of the cycle and that secondly; optimum $r_{p}$ is 20 for which the first and second law efficiencies is maximum and the specific fuel consumption minimum, thirdly ratio of power to heat increases as Turbine inlet temperature (TIT) increases fourthly, an increase in pinch point temperature decreases the first and second law efficiencies of the cycle but increases the power to heat ratio and finally that as $r_{p}$ increases exergy destruction in combustion chamber increases and as TIT increases, exergy destruction in regenerator heat exchanger increases and that combustion process accounted for over $69-73 \%$ of total exergy destruction in the overall system.

Rajan and Tariq [22] carried out an analysis evaluating the performance of a regenerative gas turbine power plant. it was observed in the research work that the thermal efficiency and power out are found to increase with the regenerative effectiveness and the compressor isentropic efficiency. The study also reported that the thermal efficiency increases with the compressor pressure ratio up to 15 and reduces with the increase of compressor pressure ratio for the regenerative model. Also, its result stated that thermal efficiency decreases as the ambient air temperature increases and increases with turbine inlet temperature. In the same vein, Mahmood and Tariq [23] also analyzed a regenerative gas turbine power plant. The paper stated that for a specific effectiveness value of a regenerator, the specific fuel consumption was reduced as the turbine inlet temperature increases. The study also mentioned that at a very low turbine inlet temperature about $1000 \mathrm{~K}$ to $1100 \mathrm{~K}$, the specific fuel consumption was found to be slightly higher at high regenerative effectiveness but decreases as the regenerative effectiveness increases at a given turbine inlet temperature,

Chacartegui et al. [4] worked on Alternative Bottoming Cycle for Combined Cycle Power Plant. The 
organic fluid considered were R113, R245, Isobutene, and Isopentane since they are dry fluids. Their study revealed that it is of no importance combining a simple gas turbine and an Organic Rankine Cycle as the efficiency rating is very low, but rather for certain organic fluid, Organic Rankine Cycle performs best when combined with a highefficiency gas turbine with a low exhaust temperature. Also, a side by side comparison of some selected organic fluid and steam as a bottoming Rankine cycle was carried out and it was gathered that the organic fluids competed favourable with steam. According to Chaczykowski [24]; Lee and Kim [25]; Sarri and Mathieu-Potvi [26] and Seta et al. [27] stated that much research should be focused on performance evaluation of bottoming ORC in gas turbine application, though Najjar and Radhawn [28] had shown that combining a regenerated Gas Turbine and ORC can result in the global thermal efficiency of $45 \%$, using R122 as working fluid.

Berrera et al. [29] studied the exergy evaluation of a Brazilian floating oil platform integrated with ORC. Cyclopentane was used as the working fluid. The results obtained revealed that the power output achieved from using the exhaust gas was favourable and savings in fuel consumption were between 15 to 20\%. Also, Reis et al. [30] analyzed the utilization of energy recovery of the exhaust gas from General Electric LM 2500 gas turbine in a floating production for organic Rankine cycle. Energy and exergy analyses of the proposed model were carried out. Results obtained showed that there was 20.3\%, $11.3 \%, 18.3 \%$ increase in electrical power generation, overall efficiency, utilization factor respectively and $22.0 \%$ reduction in carbon dioxide emission using the model. Also, the proposed model showed improvement in exergy efficiency.

Nami et al. [31] carried out a study on the application of heat recovery organic Rankine cycle of gas turbine exhaust gas waste for off shore installation. Two different configurations of the heat sources in series were considered and also investigated the exergy effects on the various heat temperatures and heat loads. The results achieved from the work showed that MM and R124 are the best working fluid for the cascade and series connections respectively. The work also reported that the viability of the application is limited to the temperature of the heat source.

Again, Bahlouli [32] investigated the use of ORCs to recover heat from a combined cycle gas turbine power plant exhaust gas to reduce the total cost of investment and increase exergy efficiency. The work reported that the capital cost reduced by $2.4 \%$ and a slight increase in exergy efficiency were obtained. Optimization of ORC configuration and conventional cycles for energy recovery from a diesel stream in an oil refinery was studied by Mazeetto et al. [33]. Maximum Power and Power/area ratio were achieved using different organic fluid.

It is observed from previous studies that ORC combined cycle can utilize waste heat at low temperatures. The gas turbine exhaust gas temperature is usually high and it may not be favourable for effective ORC combined cycle. The exhaust gas temperature needs to be reduced to a lower temperature for effective ORC combined cycle applications. Past studies have either look at integrating a regenerator in a gas turbine to improve its thermal efficiency or combined organic Rankine cycle directly. The study of incorporating a regenerator to manage the high and low exhaust gas temperature for ORC has not be addressed. So, this study is looking at incorporating a regenerator in the simple gas turbine to reduce the exhaust temperature to suit the ORC combined cycle. Therefore, this work is aims at investigating the performance effect of integrating a retrofitted combined regenerative gas turbine organic Rankine Cycle (CRGTORC) in the existing Ihovbor Power Plant.

\section{MODEL DESCRIPTIONS}

The energy analysis was carried out for the simple gas turbine (SGT) and the Combined regenerated gas turbine organic cycle model. Their performances will be compared.

\section{Simple Gas Turbine (SGT) Model}

The schematic diagram of the simple gas turbine (SGT) cycle for the existing power plant is shown in Figure 1. As illustrated in Figure 1, the air compressor takes air from the atmosphere at the state 1 . The air is compressed to state 2 and delivers it at a higher pressure into the combustion chamber where it mixes the fuel (natural gas), combustion is initiated by an electric spark (igniters) for proper burning. At state 3, the charged burnt gases are channeled into the turbine, where the thermal energy of the flue gas is converted to mechanical energy. The mechanical energy is then converted to electrical energy with the aid of the generator. The exhaust gases exit from the turbine at state 4 to the atmosphere through the stack. 


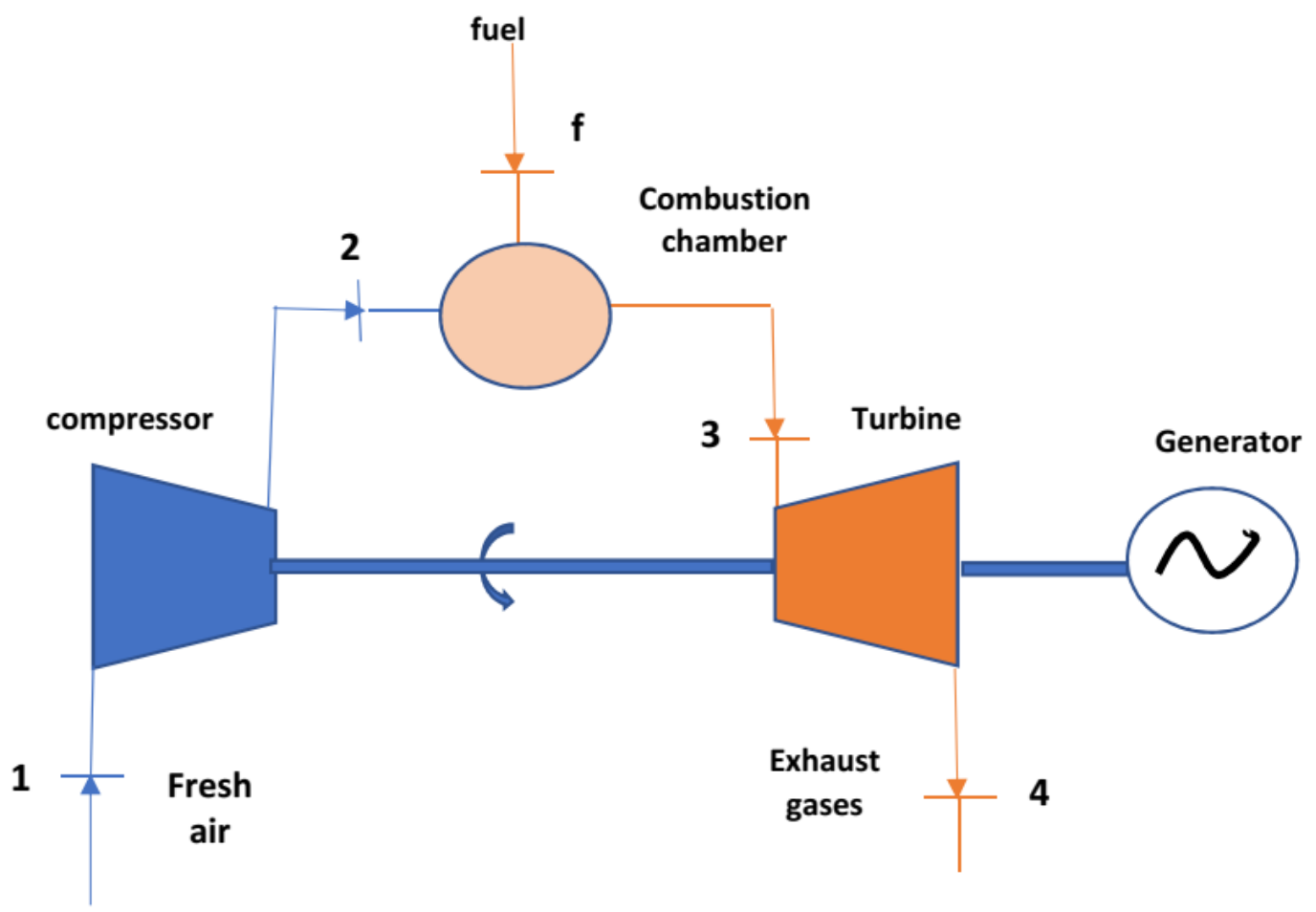

Figure. 1 Schematic Diagram of the Simple Gas Turbine

\section{Combined Regenerative Gas Turbine and Organic Rankine Cycle}

As shown in Figure 2, the CRGTORC has a regenerative gas turbine as the topping cycle while an Organic Rankine Cycle acts as the bottoming cycle. The exhaust of the regenerated Gas turbine is used to generate vapour in the Organic Rankine Cycle. The regenerator is incorporated between the air compressor exit and inlet of the combustion chamber as shown in Figure 2. The compressed air at state 2 is heated up by exhaust gas from state 4 to increase the compressed air temperature before entering into the combustion chamber and reduces the exhaust gas temperature at state 4 to state 6 .

The heat recovery vapour generator (HRVG) comprises ideally of the economizer, evaporator, superheater, blowdown connection and stack. It creates vapour for the Rankine cycle by passing the hot exhaust gas flow from a GT through the bank(s) of heat exchanger tubes. The HRVG was modelled to be a single pressure once through horizontal HRVG and the cyclopentane entered the HRVG not as a saturated liquid but directly from the feed pump as there was no preheater or economizer installed separately. Heat and Pressure loss in the HRVG was assumed to be negligible. The heat was assumed to be directly transferred from the hot exhaust gas to the cyclopentane without thermal oil or any other fluid used as an intermediary heat transfer medium.

The HRVG in the ORC utilizes the exhaust gas heat from the regenerator at state 6 to raise the temperature of the cyclopentane from state (9 to 10). The organic fluid turbine will convert the thermal energy of the fluid to mechanical energy, which is converted to electrical energy by the generator. The organic fluid from the turbine at state 11 flows through a condenser, which cooled the cyclopentane to a liquid state at 8 before it is pumped to back to the HRVG by the feed pump. 


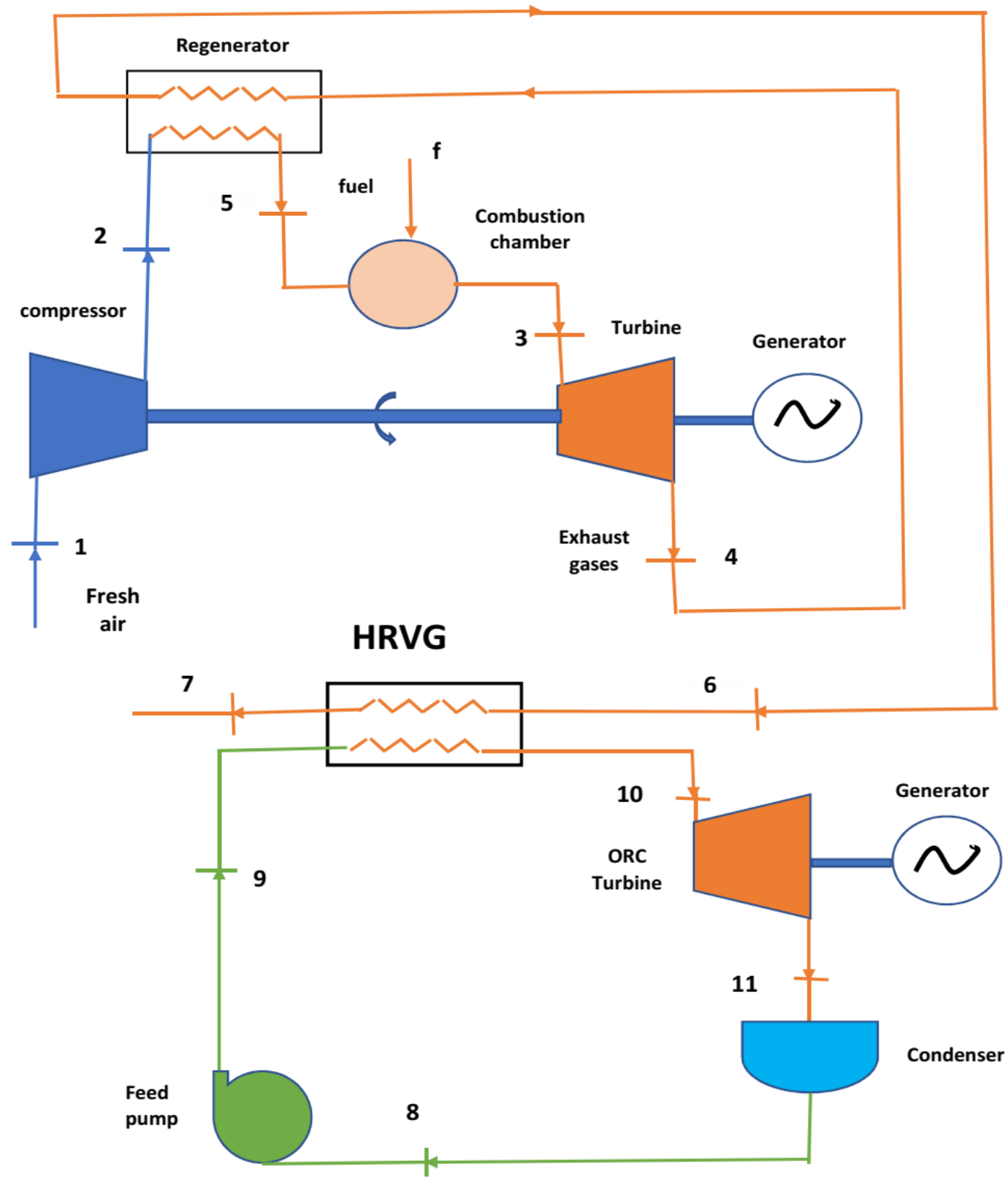

Figure 2: Schematic Diagram of Combined Regenerative Gas Turbine and Organic Rankine Cycle

The working fluid used in the ORC is cyclopentane.

The properties of the cyclopentane are as follows:

i. It has a boiling point $49.25^{\circ} \mathrm{C}$ and a molecular mass of $70.133 \mathrm{~kg} / \mathrm{kmol}$

ii. It has a low entropy change

iii. It has a negative saturation vapour line

iv. It needs lesser thermal energy to change phase from saturated liquid to saturated vapour

Cyclopentane was used as the working fluid for the Organic Rankine Cycle because of its: low Global Warming Potential (GWP) and Ozone Layer Depletion Potential (ODP) as stated in [34-36] dryness (It's a dry fluid) 37], high density/molecular mass to reduce required the mass flow rate [36], high critical pressure and temperature
[36,38], non-flammability and non-toxicity [34] and its high boiling point and low melting point at atmospheric pressure [39].

\section{ENERGY ANALYSIS}

The energy analysis was carried out for both the simple gas turbine and the combined regenerated gas turbine organic Rankine cycle.

\section{Simple Gas Turbine Analysis}

The $\mathrm{T}-\mathrm{s}$ diagram of the simple gas turbine (SGT) is illustrated in Figure 3 and its various points are used in Equations (1) to (14). 


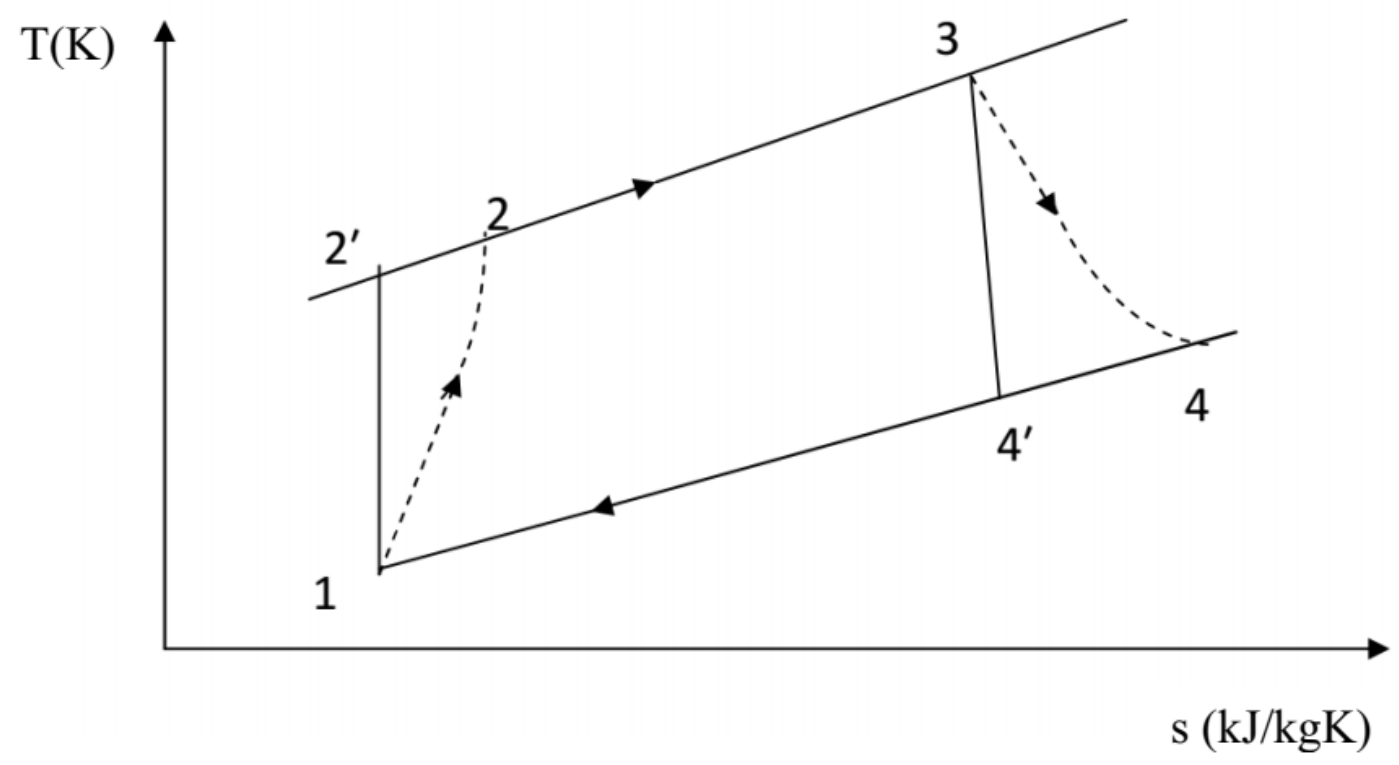

Figure 3. T-s diagram of a Gas Turbine.

In carrying out the energy analysis, the following assumptions were made:

i. There was no heat loss in the components

ii. The pressure ratio of the compressor is constant

iii. The kinetic and potential energy difference is negligible

iv. There is no pressure loss in any of the components.

v. The four units were working concurrently and had the same performance rating at any given time

vi. The combustion process to be complete.

The energy analysis for the SGT was carried out using the governing equations as expressed in Equations (1) to $(13)$.

The compressor temperature can be determined as expressed in Equation (1).

$$
T_{2}=T_{1}\left[\left(\frac{r_{p}^{\frac{\gamma-1}{\gamma}}-1}{\eta_{c}}\right)+1\right]
$$

Work done on the compressor can be evaluated as shown in Equation (2).

$$
W_{c}=\dot{m}_{a} \times c_{p a} \times\left(t_{2}-t_{1}\right)
$$

Heat supply to the gas turbine power plant can be computed using Equation (3).

$$
H S=\dot{m}_{f} \times L H V=\dot{m}_{g} \times c_{p g} \times\left(t_{3}-t_{2}\right)
$$

The turbine exit temperature can determine as expressed in Equation (4).

$$
T_{4}=T_{3}\left[1-\eta_{T}\left(1-\frac{1}{r_{p}^{\frac{\gamma_{g}-1}{\gamma_{g}}}}\right)\right]
$$

Work done by Turbine can be computed as shown in Equation (4).

$$
W_{T}=\dot{m}_{g} \times c_{p g} \times\left(t_{3}-t_{4}\right)
$$

The net power out, electrical power, thermal efficiency, work ratio (WR), specific fuel consumption (SFC), heat rate (HR) and overall cycle efficiency of the simple gas turbine (SGT) cycle can be determined using Equations (6) to (13) respectively.

Net Power output

$$
P_{n e t}=W_{T}-W_{c}
$$

$$
\begin{aligned}
& \text { The electrical power to the grid, } \\
& P_{\text {elect }}=\eta_{\text {mech }} \times \eta_{\text {gen }} \times P_{\text {net }}
\end{aligned}
$$

Flue gas Loss

$$
Q_{\text {flue }}=\dot{m}_{g} \times c_{p g} \times\left(t_{4}-t_{1}\right)
$$

Thermal efficiency

$$
\eta_{t h}=\frac{P_{n e t}}{\dot{m}_{f} \times L H V}
$$


Work Ratio

$W R=\frac{P_{n e t}}{W_{T}}$

Specific Fuel Consumption

$$
S F C=\frac{\dot{m}_{f} \times 3600}{P_{n e t}}
$$

Heat Rate

$$
H R=S F C \times L H V
$$

Overall Cycle Efficiency

$$
\eta_{o}=\frac{P_{\text {elect }}}{\dot{m}_{f} \times L H V}
$$

\section{Combined Regenerative Gas Turbine Organic Rankine Cycle Analysis}

The points in the $\mathrm{T}-\mathrm{s}$ diagrams in Figure 4 will be used in the governing equations as illustrated in Equations (14) to (27). In the CRGTORC, the gas turbine cycle part retained the formation of SGT except for the inclusion of point 5 and point 6 as shown in Figure 4. The $T-$ s diagrams of the CRGTORC are shown in Figures 4 and 5.

In carrying out the energy analysis for the CRGTORC, the following assumptions were made

i. there was no fluid leakage for the Rankine cycle along the lines and therefore no need for make-up

ii. there was blowdown in the Rankine cycles.

iii. There was no heat loss in the components

iv. The pressure ratio of the pump and the turbine is constant

v. The kinetic and potential energy difference is negligible

vi. There is no pressure loss in any of the components

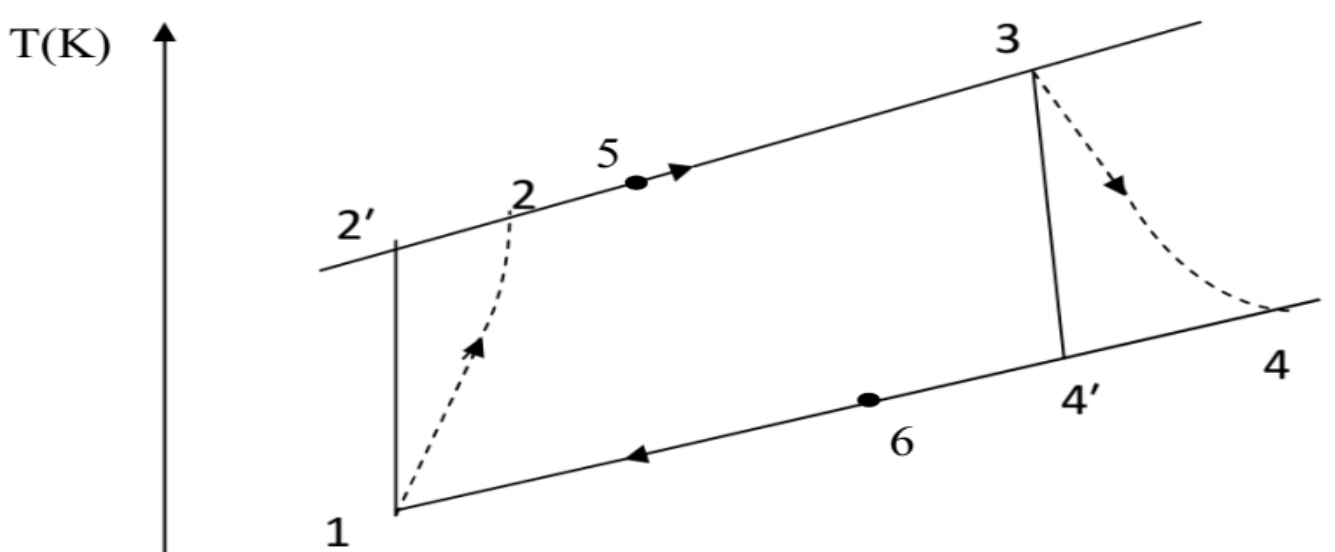

$\mathrm{s}(\mathrm{kJ} / \mathrm{kgK})$

Figure 4: T - s Diagram of a Regenerated Gas Turbine 


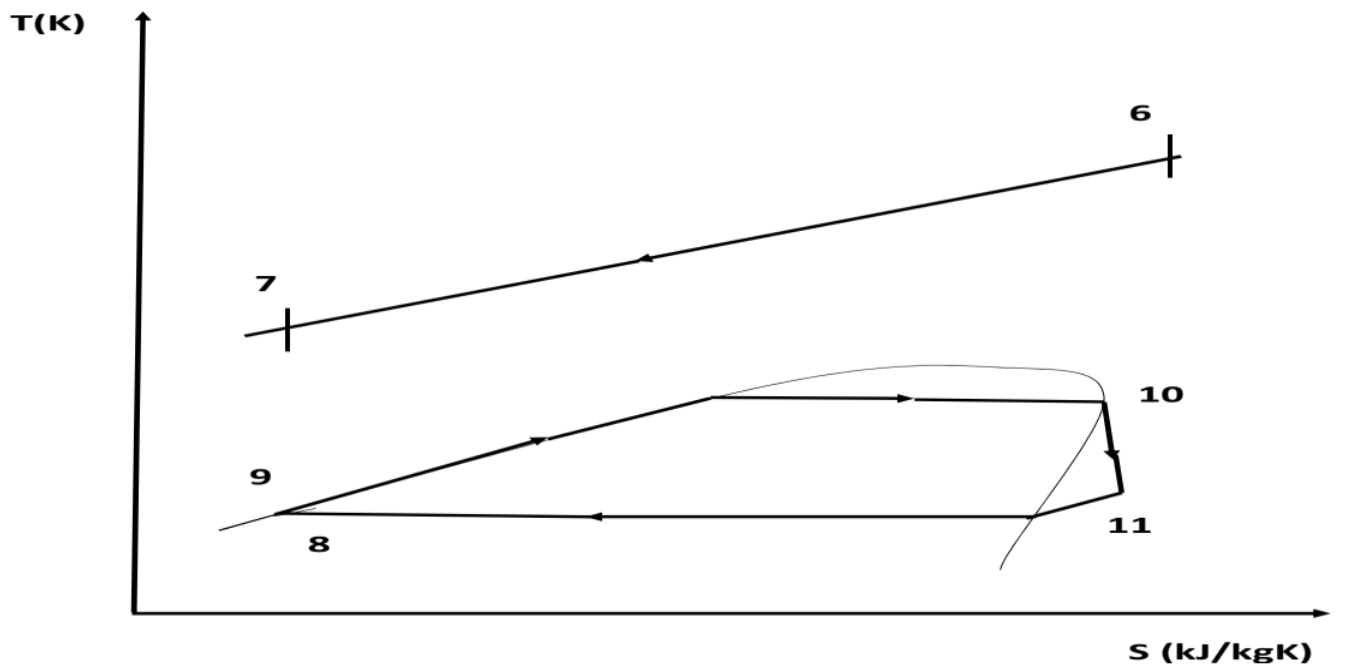

Figure 5: T- s Diagram of an Organic Rankine Cycle

The temperature at state 5 after the regenerator as shown in Figure 4 can be determine using Equation (14).

$$
T_{5}=T_{2}+\varepsilon\left(T_{4}-T_{2}\right)
$$

Heat supply for CRGTORC model is expressed as shown in Equation (15).

$$
\begin{aligned}
& H S_{\text {CRGTORC }}=\dot{m}_{f C R} \times L H V= \\
& \dot{m}_{g} \times c_{p g} \times\left(t_{3}-t_{5}\right)
\end{aligned}
$$

The turbine work, pump work, net power and electrical power output of the ORC section as shown in Figure 5 can be evaluated using Equations (16) to (19) respectively.

The Organic Fluid Turbine

$$
W_{\text {TORC }}=\dot{m}_{\text {ORC }} \times\left(h_{10}-h_{11}\right)
$$

The Pump

$$
\begin{aligned}
& \mathrm{W}_{\mathrm{p}}=\mathrm{m}_{\text {Orc }}\left(\mathrm{h}_{\mathrm{a}}-\mathrm{h}_{\mathrm{b}}\right) \\
& W_{P}=\dot{m}_{\text {ORC }} \times\left(h_{9}-h_{8}\right) \\
& P_{\text {netORC }}=W_{\text {TORC }}-W_{P} \\
& P_{\text {electORC }}=\eta_{\text {mechORC }} \times \eta_{\text {genORC }} \times P_{\text {netORC }}
\end{aligned}
$$

Equations (20) to (22) are used to determine net power out, electrical power out and flue gas loss of CRGTORC respectively.

$$
P_{\text {netCRGTORC }}=P_{\text {net }}+P_{\text {netORC }}
$$

$$
P_{\text {electCRGTORC }}=P_{\text {elect }}+P_{\text {electORC }}
$$

Flue gas Loss

$$
Q_{\text {flueCRGTORC }}=\dot{m}_{g} \times c_{p g} \times\left(t_{7}-t_{1}\right)
$$

The thermal efficiency, work ratio, specific fuel consumption, heat rate and overall cycle efficiency of CRGTORC can be determined as expressed in Equations (23) to (27) respectively.

\section{Thermal efficiency}

$$
\eta_{\text {thCRGTORC }}=\frac{P_{\text {netCRGTORC }}}{\dot{m}_{f C R} \times L H V}
$$

Work Ratio

$$
W R_{\text {CRGTORC }}=\frac{P_{\text {netCRGTORC }}}{\left(W_{T}+W_{\text {TORC }}\right)}
$$

\section{Specific Fuel Consumption}

$$
S F C_{\text {CRGTORC }}=\frac{\dot{m}_{f C R} \times 3600}{P_{\text {netCRGTORC }}}
$$

Heat Rate

$$
H R_{\text {CRGTORC }}=S F C_{\text {CRGTORC }} \times L H V
$$

Overall Cycle Efficiency

$$
\eta_{o C R G T O R C}=\frac{P_{\text {electCRGTORC }}}{\dot{m}_{f C R} \times L H V}
$$

The SGT and CRGTORC Models using APEN HYSYS are shown in Figures 6 and 7 respectively. 


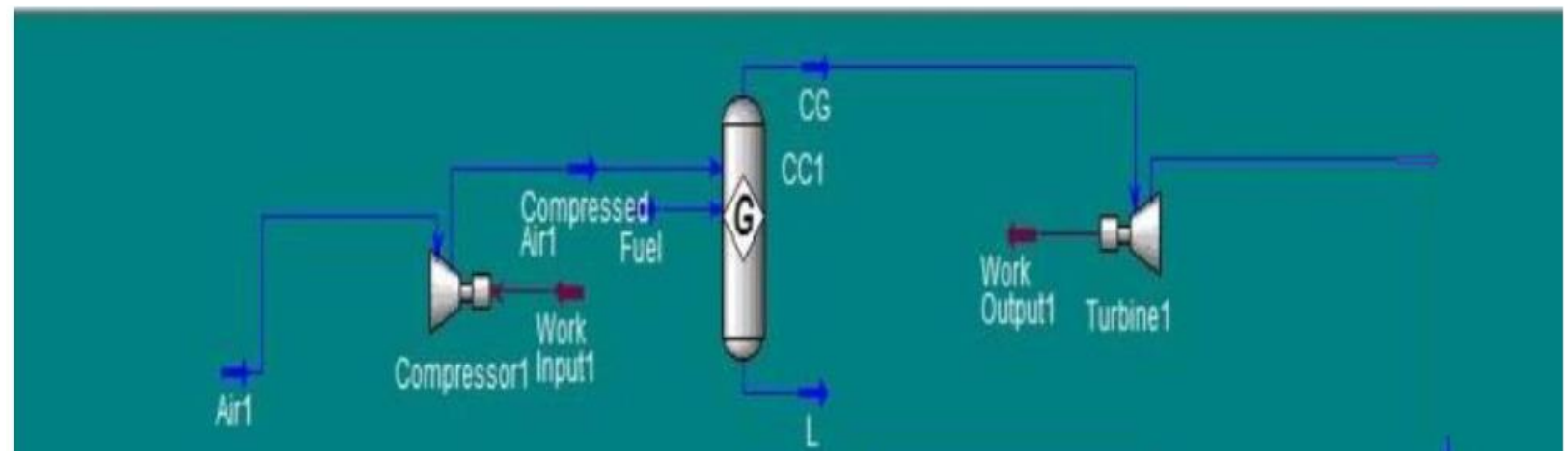

Figure 6: APEN HYSYS Flow sheet diagram of the SGT Ihovbor Power Plant

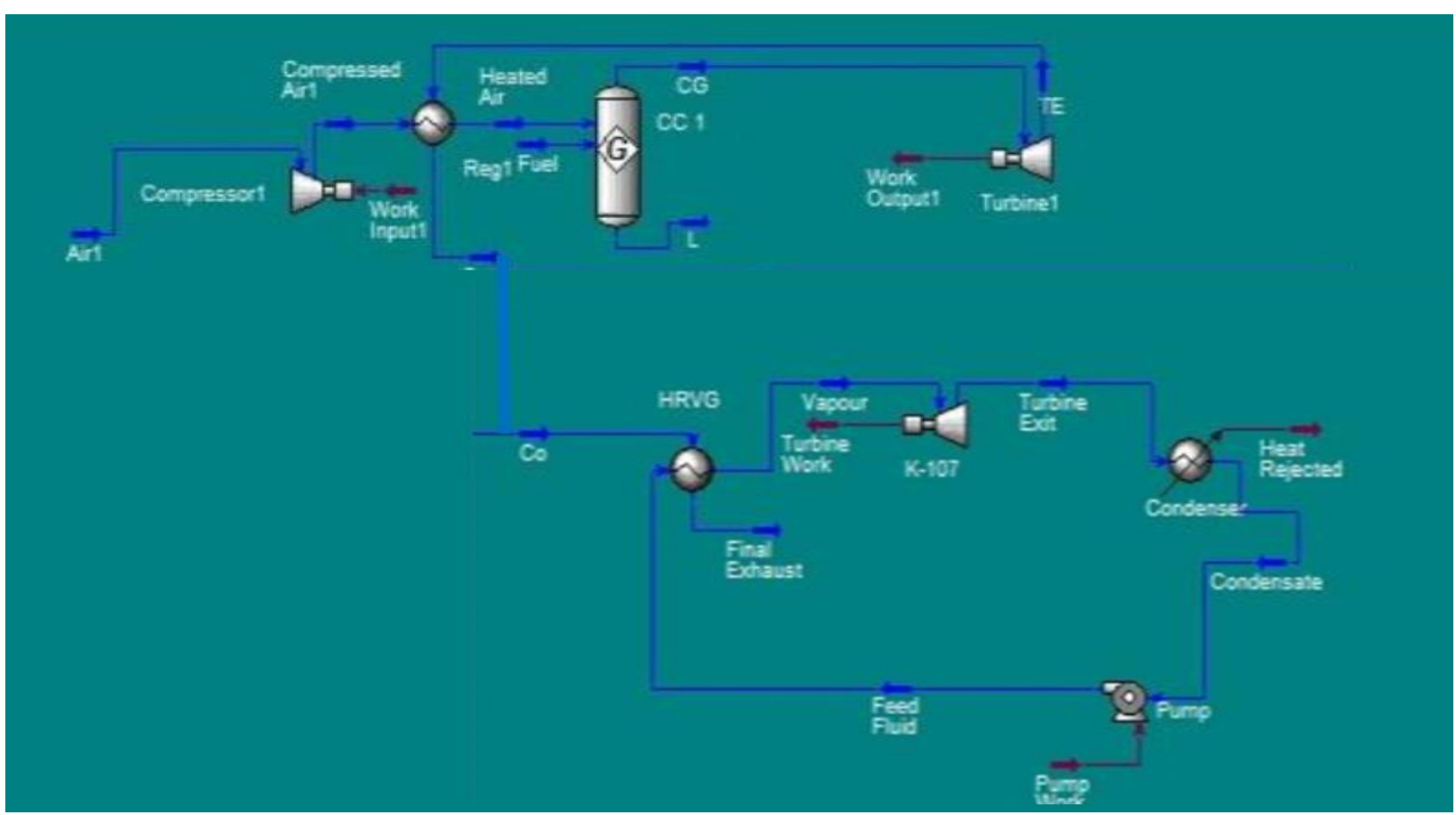

Figure 7: APEN HYSYS Flow sheet diagram of a Retrofitted Regenerated Ihovbor Power Plant Combined with an Organic Rankine Cycle

\section{RESULT and DISCUSSION}

This study on the "Energy Appraisal of a Retrofitted Organic and Steam Cycle in Ihovbor Gas Turbine Power Plant" was carried out with the aid of an Engineering Suite known as ASPEN

HYSYS [40] and REFPROP. The Software Aspen HYSYS was developed by Aspen Technology, Inc. with the trademark Aspen Tech; an America Company based in Massachusetts USA. The software is a process engineering simulation software used for the simulation of both steadystate and dynamic state processes as in the case of a Power Plant. The fluid package used for the gas component list was Peng - Robison's Equation of State. It was chosen because of it's easy to use, accurate representation of temperature, pressure and phase composition in binary and multi-components systems. REFPROP is Reference Fluid Thermodynamic Properties Database owned by America's National Institute of Standards and Technology, which was to obtained enthalpy values for the cyclopentane at various points as shown in Figure 5.

The data used for the process simulation of the gas turbine were obtained from the manual book [41] of the GE 9E frame gas turbine as shown in Table 1. 
INTERNATIONAL JOURNAL Of ENGINEERING TECHNOLOGIES-IJET

Ighodaro, et al, Vol.6, No.3, 2020

Table 1: Data for the Simple Gas Turbine

\begin{tabular}{lll}
\hline $\mathrm{S} / \mathrm{N}$ & Parameters & Value \\
\hline 1 & Ambient Air Temperature, $\mathrm{t}_{1}$ & $1{ }^{0} \mathrm{C}$ \\
2 & Ambient Air Pressure, $\mathrm{p}_{1}$ & $1.013 \mathrm{bar}$ \\
3 & Pressure Ratio, $\mathrm{r}_{\mathrm{p}}$ & 10 \\
4 & Fuel Type & Methane \\
5 & Mass flow rate of fuel, $\mathrm{m}_{\mathrm{f}}$ & $6.7 \mathrm{~kg} / \mathrm{s}$ \\
6 & Mass flow rate of air, $\mathrm{m}_{\mathrm{a}}$ & $373.3 \mathrm{~kg} / \mathrm{s}$ \\
7 & Turbine Isentropic Efficiency, $\eta_{\mathrm{T}}$ & $89.4 \%$ \\
8 & Compressor Isentropic Efficiency, $\eta_{\mathrm{c}}$ & $87.8 \%$ \\
9 & Lower heating value $(\mathrm{LHV})$ of Natural Gas & $44670 \mathrm{~kJ} / \mathrm{kg}$ \\
10 & Mechanical Efficiency, $\eta_{\mathrm{mech}}$ & $98.2 \%$ \\
11 & Generator Efficiency, $\eta_{\mathrm{gen}}$ & $98.5 \%$ \\
12 & Specific Heat Capacity of air, $\mathrm{c}_{\mathrm{pa}}$ & $1.005 \mathrm{~kJ} / \mathrm{kgK}$ \\
13 & Specific Heat Capaciity of Exhaust Gas, $\mathrm{c}_{\mathrm{pg}}$ & $1.148 \mathrm{~kJ} / \mathrm{kgK}$ \\
\hline
\end{tabular}

The data used for the retrofitted regenerative gas turbine are the same as are those used in Gas Turbine. The exceptions are the incorporated Regenerator designed with an Effectiveness of $75 \%$ and Fuel mass flow rate of 5.27 $\mathrm{kg} / \mathrm{s}$ as calculated by the Aspen Solver and other data used for the CRGTORC are presented in Table 2.

Table 1: Data for the Combined Regenerative Gas Turbine Organic Rankine Cycle

\begin{tabular}{lll}
\hline S/N & Parameters & Value \\
\hline 1 & Regenerator Effectiveness, $\varepsilon$ & $75 \%$ \\
2 & Condenser Pressure, $\mathrm{p} 11$ & $1.052 \mathrm{Bar}$ \\
3 & Turbine Inlet Pressure, p10 & $40 \mathrm{Bar}$ \\
4 & Turbine Inlet Quality (No super heating ) & 1 \\
5 & Mass flow rate of cyclopentane, $\mathrm{m}_{\mathrm{cp}}$ & $877.9 \mathrm{~kg} / \mathrm{s}$ \\
6 & Mass flow rate of fuel & $5.27 \mathrm{~kg} / \mathrm{s}$ \\
7 & Pump and Turbine Efficiencies, $\eta_{\mathrm{p}}, \eta_{\mathrm{OT}}$ & $100 \%$ \\
8 & Mechanical Efficiency, $\eta_{\text {mechCR }}$ & $85 \%$ \\
9 & Generator Efficiency, $\eta_{\text {genCR }}$ & 98.5 \\
\hline
\end{tabular}

The data in Tables 1 and 2 were used for the energy analysis of the Simple Gas Turbine (SGT), and Combined Regenerated Gas Turbine and Organic Rankine Cycle (CRGTORC) respectively. The data were simulated with the Aspen HYSYS and analyzed statistically with the aid of
Microsoft Excel. The results of electrical power out, thermal efficiency, overall cycle efficiency, flue gas losses, work ratio (WR), specific fuel consumption (SFC) and heat rate (HR) of SGT and CRGTORC are presented in Table 3.

Table 3: Average Energy Analysis performance results of SGT and CRGTORC

\begin{tabular}{clcc}
\hline S/N & \multicolumn{1}{c}{ Parameters } & SGT & Models \\
& & 115.18 & 142.28 \\
\hline 1 & Net Work (MW) & 35.62 & 57.80 \\
2 & Thermal Efficiency (\%) & 36.28 & 56.09 \\
3 & Cycle Efficiency (\%) & 224.23 & 24.19 \\
4 & Flue Gas loss (MW) & 0.4916 & 0.5418 \\
5 & Work Ratio & 0.2094 & 0.1335 \\
6 & SFC (kg/kWh) & 9773.38 & 6229.38 \\
7 & Heat Rate (kJ/kWh) & & \\
\hline
\end{tabular}


As shown in Table 3, the electrical power output, thermal efficiency overall cycle efficiency and work ratio of the system has been increased by $23.53 \%, 62.21 \%$, $54.60 \%$, and $10.21 \%$ respectively, while reduction of $89.21 \%, 36.26 \%$ and $36.26 \%$ in flue gas losses, SFC and HR respectively. Thus, results obtained revealed that the CRGTORC model has a better performance than the SGT.
The ambient air temperature was varied from $15{ }^{0} \mathrm{C}$ to $39{ }^{\circ} \mathrm{C}$ to know the effect of ambient air temperature on the energy analysis performance of the two models. The simulation results of electrical power, thermal efficiency, overall cycle efficiency, flue gas losses, WR, SFC and HR varying with ambient air temperature are illustrated in Figures 8 to 14 respectively.

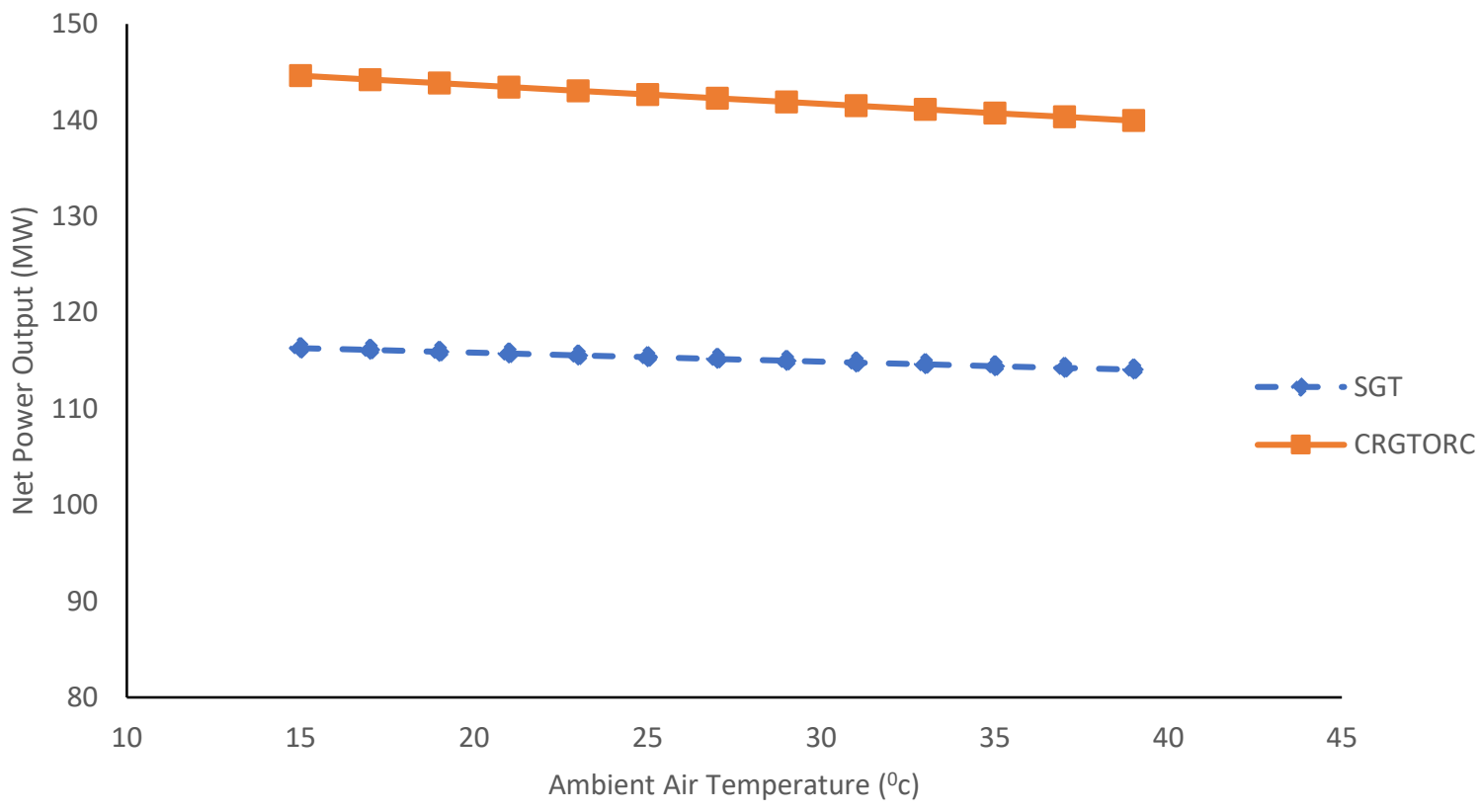

Figure 8: Variation of Electrical Power output and Ambient Air Temperature for various Cycles

As shown in Figure 8, the electrical power generated by the two cycles decreases with an increase in inlet temperature from $15^{\circ} \mathrm{C}$ to $39^{\circ} \mathrm{C}$. The CRGTORC electrical power produced was higher than the SGT as a result of the extra work produced by the bottoming cycles at the various temperatures considered. This shows the advantage of utilizing the waste flue gas heat to generate more power in the bottoming cycle by ORC.

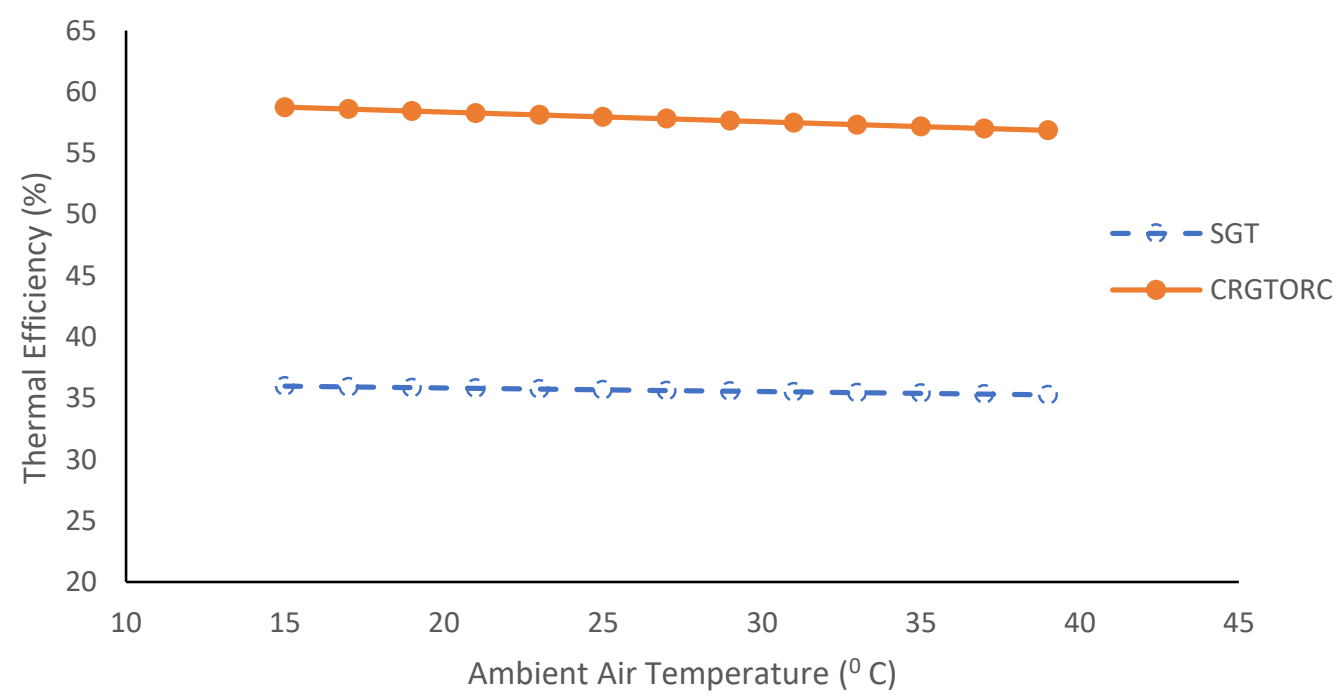

Figure 9: Variation of Thermal Efficiency and Ambient Temperature for various Cycles 
From Figure 9, the thermal efficiency of the SGT and CRGTORC decreased with an increase in ambient air temperature from $15^{\circ} \mathrm{C}$ to $39^{\circ} \mathrm{C}$. The reason being that the net power output produced by the cycles decreases with an increase in temperature for a specific/constant heat input, therefore, resulting in a decline in the thermal efficiency of the cycles. As illustrated in Figure 9, the CRGTORC has better thermal efficiency than SGT. This can be explained by the fact that the fuel consumption or heat input into the CRGTORC is lesser than that of the SGT and more power from the ORC which results in its higher thermal efficiency. This also, revealed that the model improves the thermal efficiency of the power plant it is integrated.

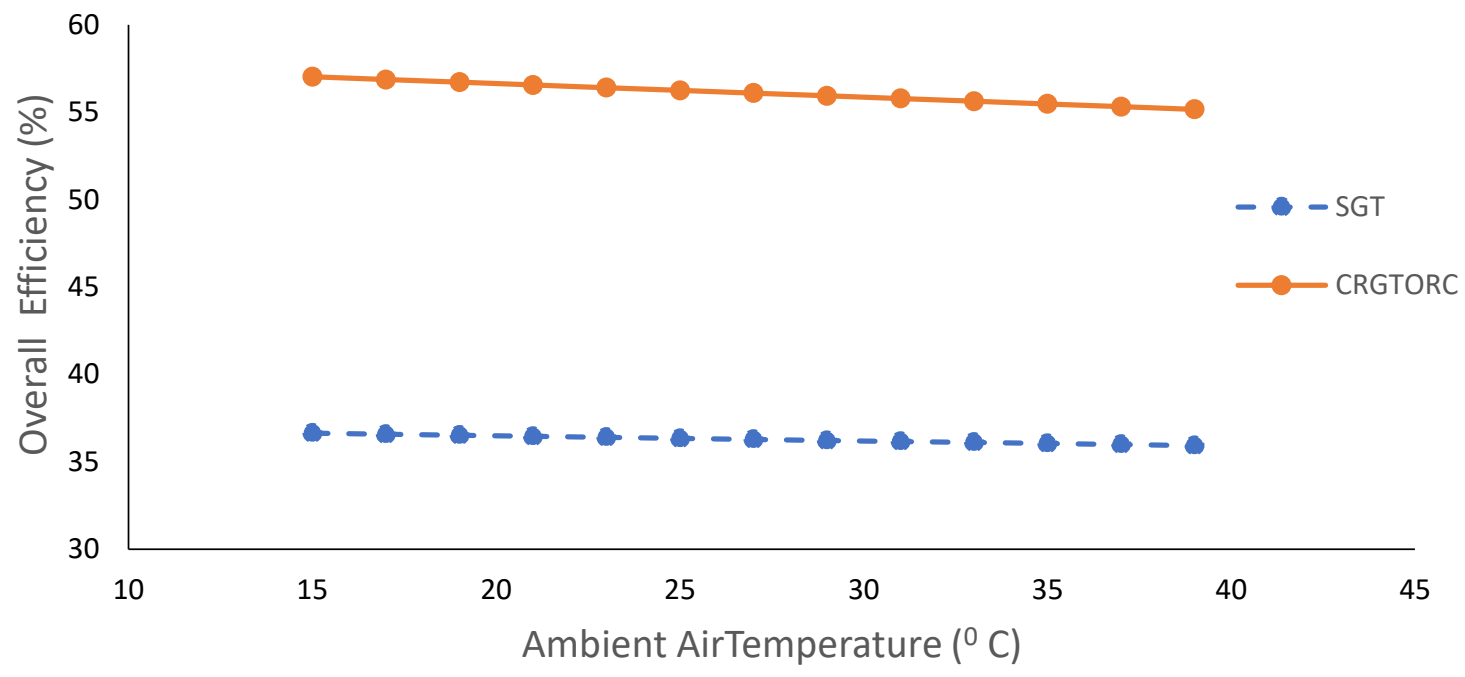

Figure 10: Variation of Overall efficiency and Ambient Air Temperature for various Cycles

The overall efficiency of the various turbines as can be seen from Figure 10 decreases with an increase in ambient air temperature from $15^{\circ} \mathrm{C}$ to $39^{\circ} \mathrm{C}$. The overall efficiency which is a measure of the overall or electrical output of a cycle decreases with ambient air temperature as a result of the decrease in electrical power output of the cycles from at constant heat/energy input which was necessitated by the increase in compressor work as the ambient air temperature increases through the turbine work increased with the increase in inlet temperature. The CRGTORC showed higher overall efficiency than the SGT at the various compressor inlet air temperatures considered. Again, the CRGTORC will improve the overall cycle efficiency of the power when incorporated.

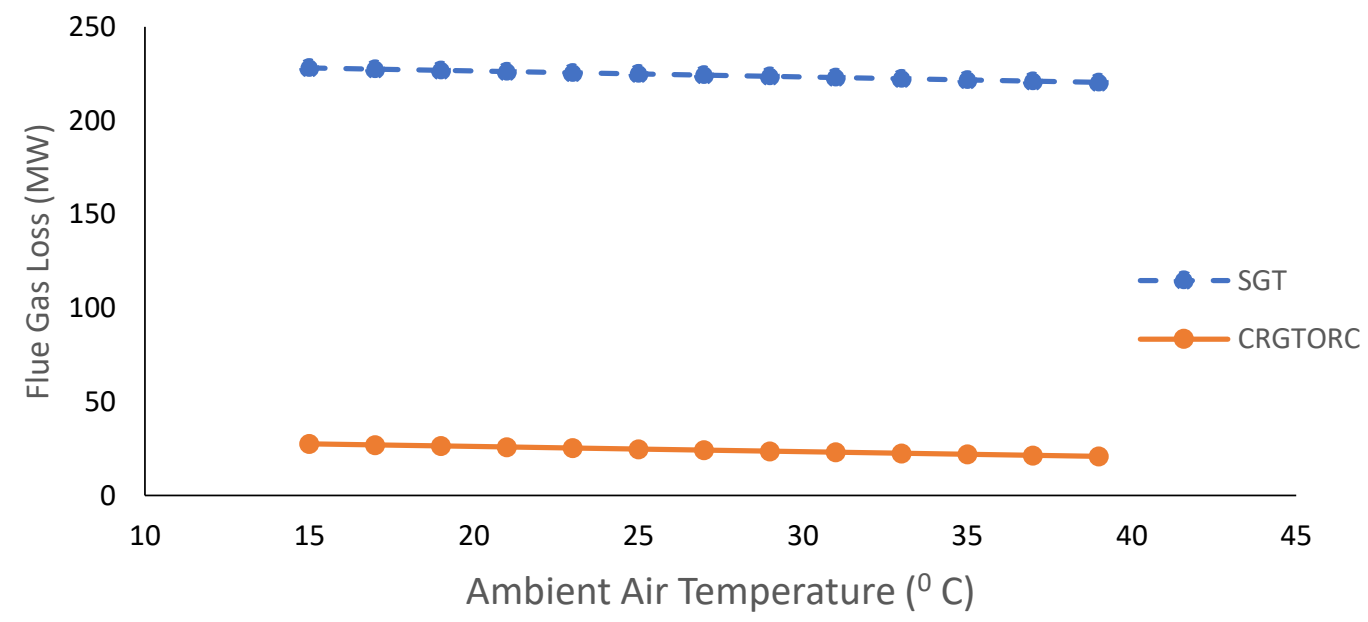

Figure 11: Variation of Flue Gas loss and Ambient Air Temperature for various Cycles 
The flue gas loss of the two cycles decreases with an increase in ambient air temperature as shown in Figure 11. The decrease of the flue gas loss across the inlet temperatures commencing from $15^{\circ} \mathrm{C}$ to $39^{\circ} \mathrm{C}$ is owed to the fact that the ambient or inlet temperature though high has been utilized more by the turbine to produce more work and therefore the difference between the exhaust temperature and inlet temperature decreases as the inlet temperature increases. The difference in temperature between the exhaust gas and the ambient air being the determining factor to the calculate the flue gas decreases in value as the ambient air temperature increases, which resulted in the decrease of the flue gas loss.

The gas turbine has the highest flue gas loss due to the poor utilization of the heat input produced by the fuel in the combustion chamber which results in high exhaust temperature. The CRGTORC has a lower flue gas loss than the SGT due to the regenerator incorporated into the gas turbine and the HRVG that utilized the waste flue gas heat. In other words, the model has helped to reduce the effect of the waste heat that would have been emitted to power plant surroundings.

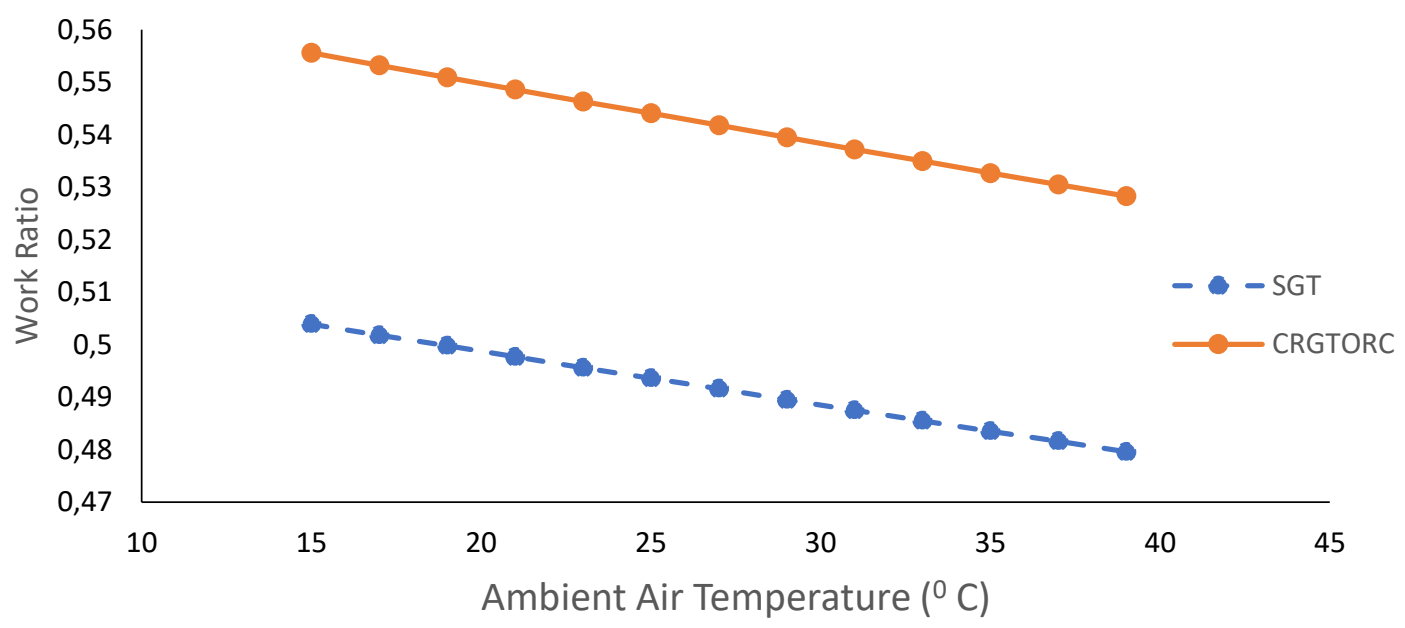

Figure 12: Variation of Work Ratio and Ambient Temperature for various Cycles

The work ratio of the various cycles as shown in Figure 12 decreases with the increase in temperature from $15^{\circ} \mathrm{C}$ to $39^{\circ} \mathrm{C}$. The work ratio is a measure of the ratio of the total turbine gross work converted into useful works i.e net power output. The decrease in work ratio is a result of the decrease in the net power output produced as the temperature increases from the increasing turbine work which increases with the increase in temperature increases from $15^{\circ} \mathrm{C}$ to $39^{\circ} \mathrm{C}$. Thus, this illustrates that the CRCTORC is less susceptible to irreversibility since it has a higher work ratio.

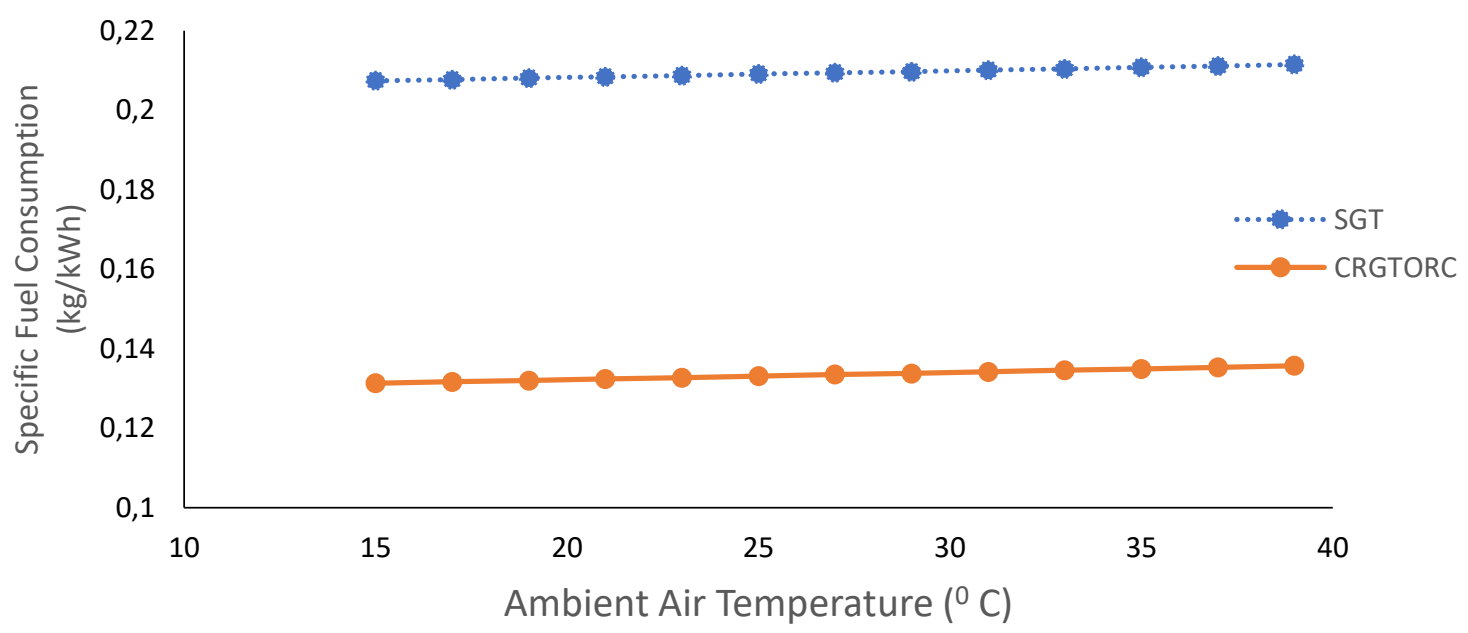

Figure 13: Variation of SFC and Ambient Air Temperature for various Cycles 
The specific fuel consumption increases with an increase in temperature from $15^{\circ} \mathrm{C}$ to $39^{\circ} \mathrm{C}$ as observed in Figure 13. SFC is a measure of the mass of the fuel used to produce one (1) Kilowatts of Power in an hour. The increase in SFC was necessitated by the reduction in thermal power produced by the cycles with an increase in temperature from constant fuel consumption by the combustion chamber.
The SGT has the highest SFC due to the low thermal power produced by the SGT from the fuel combusted in the combustion chamber. The CRGTORC has the lower SFC due to the low fuel consumed as a result of the fuel savings as a result of the regeneration of the Gas Turbine. The CRGTORC model again showed that less fuel will be required compare to when SGT is used.

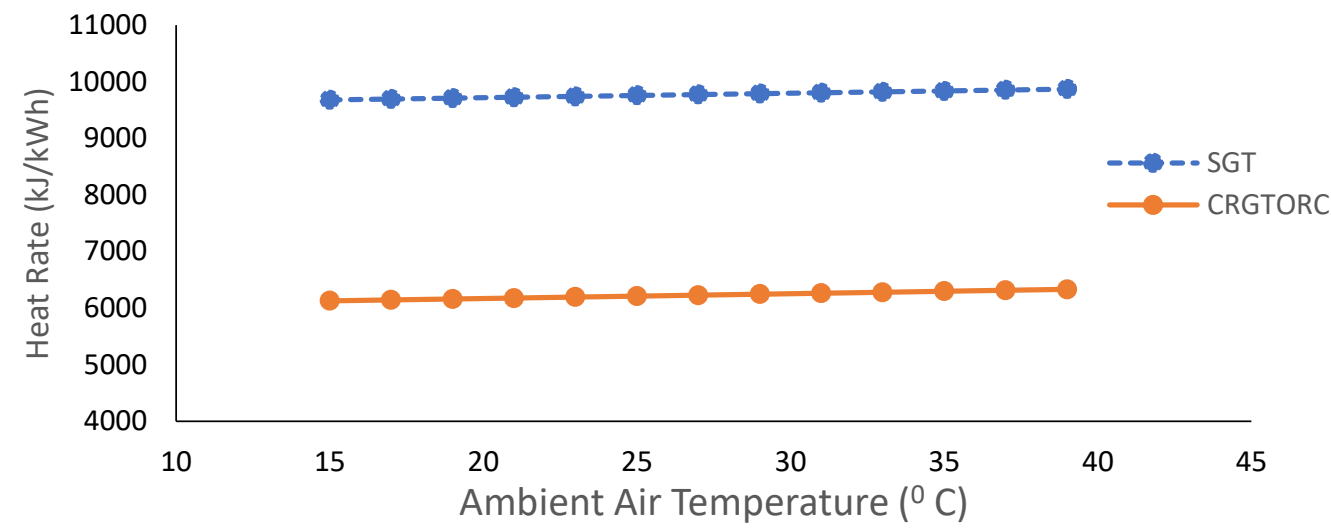

Figure 14: Variation of Heat Rate and Ambient Temperature for various Cycles

Figure 14 shows that the heat rate increased with an increase in temperature as the temperature increased from $15^{\circ} \mathrm{C}$ to $39^{\circ} \mathrm{C}$. The increase in heat rate which is a measure of the heat converted into one Kilowatt of Power in an hour is as a result of the decrease in thermal power produced with the increase in temperature at constant heat input as a result of the constant fuel consumption.

The SGT had the highest Heat rate as a result of its lower thermal efficiency and net power out compared to CRGTORC. The model will improve the heat rate of the power plant because it will require less heat energy to generate equivalent power.

\subsection{Conclusion}

The energy analysis of the SGT and retrofitted CRGTORC of Ihovbor Power Plant was carried out. The analysis was performed by using ASPEN HYSYS with the thermodynamic governing equations for energy analysis. The results obtained revealed that the CRGTORC model performed better than the SGT because the net power

\section{References}

[1]. Kirshen DS and Strbac G. (2018) Fundamental of Power system Economics. $2^{\text {nd }}$ ed. University of Washington USA.

[2]. De Campos GB, Bringheti C, Traverso A, Tomita J $\mathrm{T}$,(2020) Thermoeconomic Optimization of Organic Rankine Bottoming Cycles for micro gas turbines, Applied Thermal Engineering 164; 114477. output, thermal efficiency, overall cycle efficiency, and work ratio was increased while flue gas losses, specific fuel consumption and heat rate were reduced compared. Both cycles performances were affected by the ambient air temperature. Thus, incorporation of CRGTORC in the existing Ihovbor Power plant should be encouraged to improve its design performance. The study of integrating the compressor inlet air cooling system is recommended to mitigate the effects of ambient air temperature on the CRGTORC model.

\section{Acknowledgement}

The authors appreciate the staff of Niger Delta Power Holding Company (NDPHC): Benin Generating Station, Ihovbor, Edo State, Nigeria for providing the data and technical information used for this research work.

\section{Disclosure statement} the author(s).

No potential conflict of interest was reported by

[3]. Mendoza E, Lin T, Jiang X, (2015) Reduction of gas turbine exhaust temperature limit due to HRSG limitations by change on control curve to optimize plant operation and performance. InASME Turbo Expo 2015: turbine technical conference and exposition 2015. American Society of Mechanical Engineers Digital Collection. 
[4]. Chacartegui R., Sanchez D., Munoz J. M., Sanchez T, (2009) Alternative Orc Bottoming Cycles for Combined Cycle Power Plants. Applied Energy, Vol. 86 pp. 2162-2170.

[5]. Wang X., Yang Y., Wang M., Zheng Y., Wang J., Dai Y, (2015) Utilization of Waste Heat from Intercooled, Reheat and Recuperated Gas Turbines for Power Generation in Organic Rankine Cycles. 3rd International Seminar on ORC Power Systems, October 12-14, 2015, Brussels, Belgium.

[6]. Mohanty D. K., Venkatesh V, (2014) Performance Analysis of a Combined Cycle Gas Turbine under Varying Operating Conditions; Mechanical Engineering: An International Journal (MEIJ) Vol. 1, No. 2. pp 11-25.

[7]. Lebele-Alawa TB, and Le-Ol AK, (2015) Improved Design of a 25 MW Gas Turbine Plant Using Combined Cycle Application, Journal of Power and Energy Engineering, 2015, Vol. 8, No 3, pp 1-14.

[8]. Yamamoto T, Furuhata T, Arai N. Mori K, (2001) Design and testing of the Organic Rankine Cycle, Energy Vol. 26, Issue 3, pp. 239-251.

[9]. Tachanche BF, Lambrinos G, Frangoudakis A, Papadakis G,(2011) Low grade heat conversion into power using organic Rankine Cycles - a review of various applications. Renew Sustain Energy Rev 15 (8): $3963-79$.

[10]. Velez F, Chejne F, Antolin G, Quijano A, (2012) Theoretical Analysis of a Trans critical power cycle for power generation from waste energy at low temperature heat source. Energy Convers manage 60: $188-95$.

[11]. Lecompte S, Huisseune $\mathrm{H}$, van den Broek $\mathrm{M}$, Vanslambrouck B, de Paepe M, (2015) Review of organic Rankine cycle (ORC) architectures for waste heat recovery. Renew Sustain Energy Rev 47: $448-61$.

[12]. Najjar YS (2001). Efficient Use of Energy by Utilizing Gas Turbine Combined System. Applied Thermal Engineering Vol. 21, Issue 4 pp. 407-438.

[13]. Khaljani M., Saray R. K., and Bahlouli K, (2015) Thermodynamic and Thermoeconomic Optimization of An Integrated Gas Turbine and Organic Rankine Cycle. Energy, Vol. 93, Part 2 pp. 2136-2145.

[14]. Grelet V, Reiche T, Lemort V, Nadri M, Dufour P, (2016) Transient Performance Evaluation of Waste Heat Recovery Rankine Cycle Based System for Heavy Duty Trucks. Applied Energy Vol. 165 pp. 878-892.

[15]. Mohammadi A., Kasaeian A., Pourfayaz F., Ahmadi M. H (2017) Thermodynamic Analysis of a Combined Gas Turbine, ORC Cycle and
Absorption Refrigeration for a CCHP System. Applied Thermal Engineering Vol. 11 pp. 397-406.

[16]. Caresana F., Comodi G., Pelagalli L., Vagni S, (2008) Micro Combined Plant with Gas Turbine and Organic Cycle Proceedings of ASME Turbo Expo 2008.

[17]. Yari M, (2008) Thermodynamics Analysis of a Combined Micro Turbine with a Micro ORC; ASME Turbo Expo 2008: Power for Land, Sea, and Air.

[18]. Invernizzi C, Iora P, Silva P, (2011) Bottoming micro-Rankine cycles for micro-gas turbines, Applied Thermal Engineering Vol. 27(1); pp. 100110 .

[19]. Nurhilal O., Mulyana C., Suhendi N., and Sapdiana D, (2016) The Simulation of Organic Rankine Cycle Power Plant with n-Pentane Working Fluid. AIP Conference Proceedings, 2016.

[20]. Meyer D., Wong C., Engel F. and Krumdieck S, (2013) Design and Build of a $1 \mathrm{~kW}$ Organic Rankine Cycle Power Generato. $35^{\text {th }}$ New Zealand Geothermal Workshop: 2013 Proceedings; University of Canterbury, New Zealand.

[21]. Kumar A, Kachhwaha SS, Mishra RS, (2010) Thermodynamics Analysis of a Regenerative Gas Turbine Cogeneration Plant. Journal of Scientific and Industrial Research Vol. 69(3) pp. 225-231.

[22]. Ranjan R. and Tariq M, (2014) Analysis of a Regenerative Gas Turbine Cycle for Performance Evaluation. International Journal of Engineering Research and General Science Vol. 2, Issue 4, pp. 792-801.

[23]. Mahmood OS. and Tariq M, (2014) Analysis of a Regenerative Gas Turbine Cycle for Power Plant; International Journal of Scientific Engineering and Technology Research Vol.03, Issue 04, pp. 06110616.

[24]. Chaczykowski, M, (2016) Organic Rankine Cycle for Residual Heat to Power Conversion in Natural Gas Compressor Station Part II: Plant Simulation and Optimisation Study. Arch. Min. Sci., Vol. 61, No 2 pp. 259-274.

[25]. Lee HY and Kim KH, (2015) Energy and Exergy Analyses of a Combined Power Cycle Using the Organic Rankine Cycle and The Cold Energy of Liquefied Natural Gas. Entropy 17, pp. 6412-6432.

[26]. Sarr J. R., And Mathieu-Potvi F, (2016) Increasing Thermal Efficiency of Rankine Cycles By Using Refrigeration Cycles: A Theoretical Analysis. Energy Conversion And Management, Vol. 121 pp. 358-379.

[27]. Seta A. L., Meroni A., Andreasen J. G., Pierobon L., Persico G., Haglind F, (2016) Combined 
Turbine and Cycle Optimization for Organic Rankine Cycle Power Systems-Part B: Application on A Case Study. Energies Vol. 9,

[28]. Najjar Y. S. H. and Radhawn A. M, (1988) Cogeneration by Combining Gas Turbine Engine with an Organic Rankine Cycle, Heat Recovery Systems and CHP, 1988 Vol. 8, Issue 3, pp. 211219.

[29]. Berrera JE, Bazzo E, Kami E, (2015) Exergy analysis and energy improvement of a Brazialian floating oil platform using Oranginc Rankine Cycles. Energy 88: 6779.

[30]. Reis MML, Guillen J A V, Gallo WLR, (2019) Off design performance analysis and optimization of the power production by an organic Rankine cycle coupled with gas turbine in an Offshore oil plant form, Energy Conversion and Management 196: 1037 - 1050.

[31]. Nami H, Ertesvag JS, Agromayor R, Roboldi L, Nord L.O (2018) Gas turbine exhaust gas heat recovery by organic rankine Cycles (ORC) for off shore combined and power applications - Energy and exergy analysis, Energy 165: 1060 - 1071.

[32]. Batilouli K, (2018) Mutlti-Objective Optimization of a combined cycle using exergetic and exergoeconomic approaches. Energy Convers Manage 171: 1761 - 72.

[33]. Mazetto BM, Silva JAM, (2015) Oliveira S. Are ORCs a good option for waste heat recovery in a petroleum refinery? Int. J. Thermodyn 18: $206-11$.

[34]. Calm J. M., Hourahan G. C, (2011) Physical, Safety and Environmental data for current and alternative Refrigerants, ICR 2011, August 21 - 26 Prague, Czech Republic

[35]. Nouman J, (2012) Comprative Studies and Analysis of Working Fluids for Organic Rankine CyclesORC. Master of Science Thesis, KTH School of Engineering and Management 2012.

[36]. Vivian J., Manente G., Lazzaretto A, (2015) A General Framework to Select Working Fluid and Configuration of ORCs for Low-To-Medium Temperature Heat Sources. Applied Energy Vol. 156, pp. 727-746.

[37]. Ekwonu M. C., Perry S., Oyedoh E. A, (2014) Modelling of Gas Engines Integrated with Organic Rankine Cycle and Rankine Cycle; Advanced Chemical Engineering Research Vol. 3(1), pp. 4347.

[38]. Reza R, (2016) Performance and Cost Evaluation of Organic Rankine Cycle at Different Technologies.
Master of Engineering Degree Thesis, Department of Sustainable Energy, KTH, Sweden. 2016.

[39]. Mago P. J., Chamra L. M. and Somayaji C, (2007) Performance Analysis Of Differrent Working Fluids for Use In Organic Rankine Cycles. Proceedings of the Institution of Mechanical Engineers, Part A, Journal of Power and EnergyVol.22 (3), pp 255 - 264.

[40]. ASPEN HYSYS, (2016) version 9.0 ASPEN power generation and Refrigeration library manual.PSE version 9.0 ed USA ASPEN Simulation Technology INC, 200-wheeler Road Burlington MA 2016

[41]. NDPHC, (2014) Draft Technical Specifications for GE Frame PG9171E Gas Turbine Generator and Direct Auxiliaries and Limits of Supply. 
Ighodaro, et al, Vol.6, No.3, 2020

\section{Appendix - NOMENCLATURE}

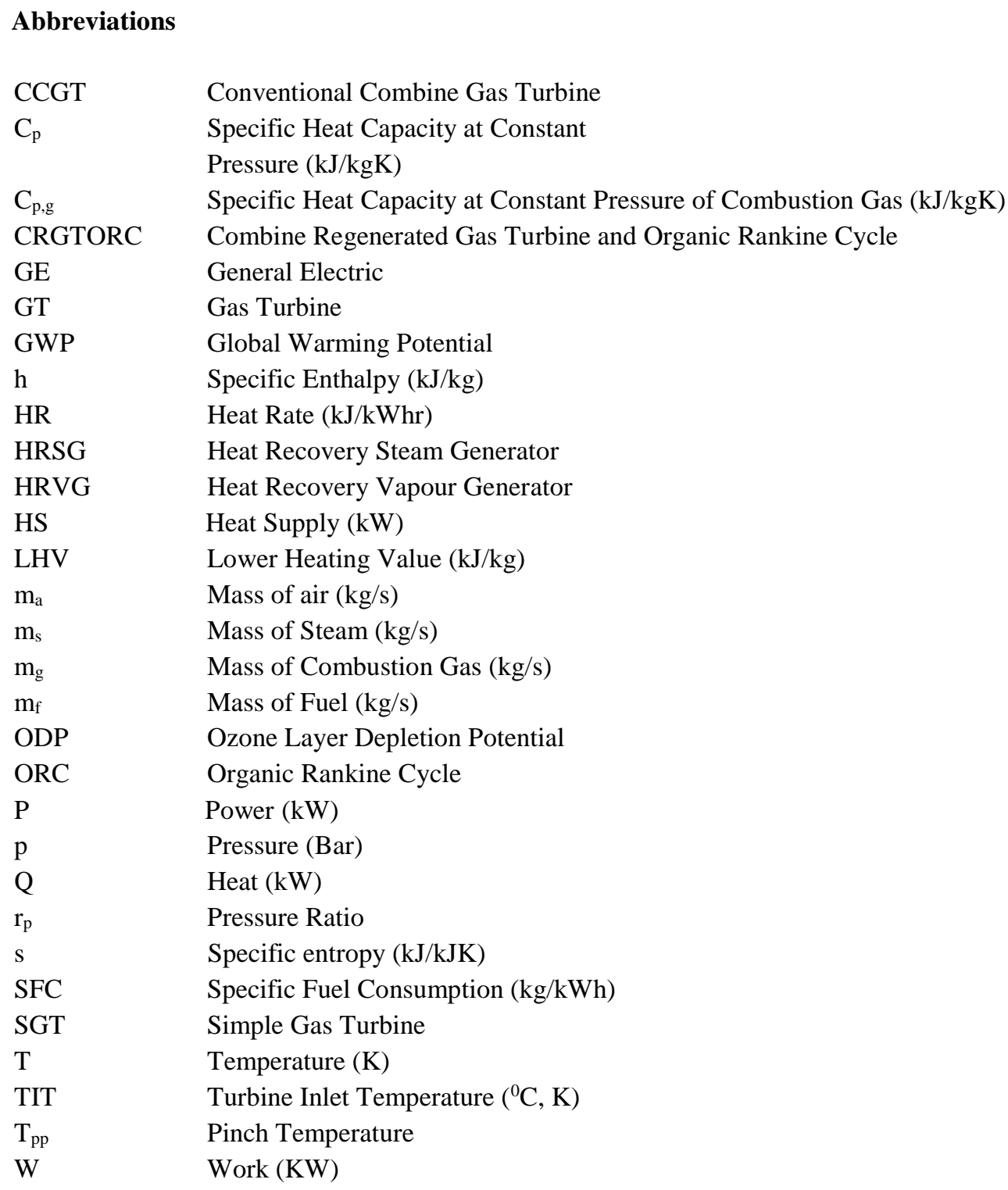

\section{GREEK SYMBOLS}

$\eta$

\section{SUBSCRIPTS}

a

c

Efficiency

Gas Constant

Regenerator Effectiveness

Air

Compressor

Fuel

Combustion Gas

Gas Turbine

Mechanical

Overall

Pump

Steam

Steam Turbine

Turbine

Thermal 